\title{
Experiencing and Privately Remembering Late Albanian Socialism: A Study Based on Oral History Interviews in the Region of Shkodra
}

\author{
Idrit Idrizi
}

\author{
Postdoctoral Fellow, \\ Austrian Academy of Sciences
}

Doi: 10.2478/mjss-2018-0101

\begin{abstract}
Based on interviews with 35 contemporary witnesses, this paper examines how Albanian socialism's late phase (second half of the 1970s and first half of the 1980s) was subjectively experienced and is individually remembered today. It argues that despite harsh state repression and considerable impoverishment in this period, the communist regime enjoyed the loyalty of large sections of the country's population. Furthermore, the paper suggests that many contemporaries have yet to come to terms with their experiences of that time. Their recollection narratives are predominantly characterised by uncertainties and contradictions, of which both individuals and society still have to make sense.
\end{abstract}

Keywords: Communist Albania, Post-communist Albania, Late Socialism, Socialism Remembrance, Oral History

\section{Introduction}

The Albanian communist system is generally considered to have been one of the most repressive and ideologically rigid in the Eastern bloc, while belonging to the least researched ones. The regime's radical and peculiar policies and ideology have been attracting some scholarly attention already during Cold War. ${ }^{1}$ However, there is still little known on the experiences of the population, which in the 1970s and 1980s was isolated from the rest of the world to an almost unique extent. ${ }^{2}$ Furthermore, there are only very few studies on the way such experiences are recollected and dealt with today. ${ }^{3}$ Based on interviews with 35 contemporary witnesses conducted in 2012, this paper contributes to research on both socialism and socialism remembrance in Albania. Analysing the respondents' experiences and personal memories in depth and contextualising them historically and theoretically, the study adds to prior research on rigid dictatorial systems and their legacies.

\footnotetext{
${ }^{1}$ For a summary of the state of research, see Schmidt-Neke, 2009 and Idrizi, 2014: 100-5. The most comprehensive overview of history of Albania under communism is provided by Grothusen (Ed.), 1993. Regarding the peculiarities of the Albanian communist system and ideology, see especially: Pipa, 1990; Prifti, 1978; Tönnes, 1980. Concerning political repression, see among others: Amnesty International, 1984; Minnesota Lawyers International Human Rights Committee, 1990; Kretsi, 2007a and 2007b.

${ }^{2}$ The most comprehensive publications are: Kretsi, 2007a; Woodcock, 2016. Following publications feature the transcripts of interviews and/or tell the life stories of mainly former political prisoners: Niegelhell \& Ponisch, 2001; Kati, 2004; Instituti i Studimeve për Krimet dhe Pasojat e Komunizmit (Ed.), 2014/2015/2016. Of relevance are also following articles: Vullnetari \& King, 2014; Vullnetari \& King, 2016a; Vullnetari \& King, 2016b; Woodcock, 2007.

${ }^{3}$ Beside publications cited in the previous footnote, following studies are most relevant: Amy, 2010; lacono \& Këlliçi, 2015; lacono \& Këlliçi, 2016; Lelaj, 2016; Woodcock, 2014.
} 


\section{Sources and Methodology}

The interviews focused on the private recollection of the second half of the 1970s and the first half of the 1980s, a period that corresponds with the final phase of the era of Enver Hoxha and was marked by a rigidly isolationist foreign policy, increasing state pressure and drastic economic decline. ${ }^{4}$ In order to explore the population's perspective, no contemporaries who have held high political positions (except for membership of local party organisations in four cases) were interviewed. Furthermore, among the respondents were six individuals who had been discriminated because of their political-social background, but no former political prisoners, since researching this specific group in-depth would go beyond the scope of this paper. The sample included interviewees of different generations (one born in 1929, five in the 1930s, eleven in the 1940s, eight in the 1950s and ten in the 1960s) and nine women and 26 men. Due to practical reasons, all interviewees were recruited in the region of Shkodra, in a relatively balanced proportion between city and surrounding villages. Having regard to the profile of the interviewees, the paper maintains that their geographical origin does not substantially influence their responses, and thus, the study's results. The interviews were designed as semi-structured, but the respondents was left large room to talk about experiences and issues they found important themselves. As arranged with the interviewees, for reasons of anonymity and confidentiality, their names cited in this and other publications have been replaced with alias names.

The methodology used to analyze the data follows the technique "empirically grounded construction of types and typologies in qualitative social research" designed by Susann Kluge in order to elaborate both distinctions and commonalities among the respondents (Kluge, 2000). On the one hand, retrospective recollections are regarded not as simple revelations of past realities, but as part of a respondent's identity-constructing process, influenced by many factors and subject to lifelong modifications and reinterpretations. ${ }^{5}$ On the other hand, the paper tries to make use of the great potential of oral history interviews to not only research remembrance but also to approach the past, and especially aspects that are barely or inadequately addressed in written sources (cf. ibid., 44-7, 54).

\section{Typology of Experiences and Recollection Narratives}

\subsection{A 'normal life'}

Recollecting life in the second half of the 1970s and first half of the 1980s, a significant number of interviewees explicitly or implicitly maintained that it had been 'just normal'. Remarkably, while they emphasised the period's pervasive poverty and claimed to have been well aware of the state's repression, they averred that one could achieve 'private happiness' despite and alongside these conditions. This section will examine both the respondents' former strategies to adapt to the conditions in late socialism as well as their retrospective arguing about its 'normalcy'.

The narratives of the interviewees in this category centred on memories of working and mastering the burdensome daily life. Such activities were described as exhausting, yet they were connoted very positively. Working, in the broader sense, was depicted as both a survival necessity and a central source of happiness. Politics, meanwhile, were almost completely absent from these stories. When directly asked, interviewees typically pointed out that the 'political sphere' was completely irrelevant for them, and then continued to present their daily routine. ${ }^{6}$

This focusing on one's own competences in mastering daily life and the exclusion of politics

\footnotetext{
${ }^{4}$ See especially the 'Innenpolitik', 'Außenpolitik', 'Politisches System', 'Rechtssystem', 'Land- und Forstwirtschaft' and 'Außenwirtschaft' chapters in Grothusen (Ed.), 1993: 57-85, 86-156, 169-242, 243-88, 343-75, 427-51.

${ }^{5}$ The methodological challenges of Oral History have been the subject of numerous studies. A useful overview is presented in Obertreis \& Stephan, 2009.

${ }^{6}$ Take, for example, Ms Latifi's answer to a question about her perception of the isolationist policy. Having stated very briefly that her knowledge about this issue was extremely restricted, she went on - without establishing any logical connection - to present in detail her daily routine of mastering both working and managing the household: Transcript (henceforth: Tscp.) no. 29, 2.
} 
from life story narratives are well-known phenomena for scholars working with oral testimonies about socialism. Through such responses, contemporary witnesses may claim their 'right to happiness' and react against radical anti-communist discourses that tend to condemn and devaluate everything connected to socialism. ${ }^{7}$ However, explaining the interviewees' narrative of a normal and completely apolitical life simply through these motives would fall short, as the following analysis of three specific accounts demonstrates.

To the most typical interviewees in this category belongs Ms Brahja. She repeatedly stressed the great scarcities of the socialist period and the harsh punishments for political transgressions, but indicated several times that poverty and state repression did not bother her then. Born in 1962, she belonged to a generation that took these conditions as given. Her habitus in socialism might be best characterised as 'unthinking - even unconscious - conformity' (Fulbrook, 1995: 273). In socialist time, she never questioned the normality of the 'world' in which she was born and socialised; instead, she almost exclusively focused on mastering her burdensome daily life. However, the interviewee did not describe her efforts in this respect as heroic. As the following quote demonstrates, her narrative about the 'socialist normalcy' included talking about shameful experiences when judged retrospectively:

I swear to God, when we think today about what he [Enver Hoxha] said, [we think that] he told us only lies ... nothing true, but, at that time, I swear to God, we did not have enough time to wash clothes ... [to critically examine the official discourse, far less] (tscp. no. 25: 5).

We were like animals. [...] Working, eating, striving to ensure the daily bread for the children at home, not talking anything at all with nobody [sic] (ibid.: 10).

By contrast, another interviewee, Mr Guri, who was born in 1939, did not take the conditions under socialism as given, but became accustomed to them over time. This process was driven by a fear of repression and a tendency to adjust to dominant social behavioural patterns, and involved a continuous self-education toward conformism:

\begin{abstract}
Well, so to say, I used to not engage myself in such things [reflecting on politics], but, so to say, I did think sometime something, and [but then I thought:] ... 'What the State says, one should stay ready [to implement it]! "Aye-aye, sir!"'. And why [did I think like that]? Because one could not speak [freely]. And why [could one not speak freely]? Because he [Enver Hoxha] imprisoned you. [...] All were like - how should I say it - all were with Enver, 'Aye-aye, sir!'. Enver had [enforced] some strict rules, strict regimes [a strict political order]. Such things like [politically incorrectly] talking - aaaa, he imprisoned you [for that]. Because of a single [politically inappropriate] word, he imprisoned you (tscp. no. 5: 5).
\end{abstract}

Such rigorous conformism brought about, over time, an adaptation to socialism. Guided by the maxim 'With the others! Like all the others!' (ibid.: 8) and reasoning 'I am eating what others eat; I am earning as much as others earn' (Ibid.) and 'We work, eat a piece of bread, live' (ibid.: 4.), Mr Guri went on to perceive the given conditions as at least acceptable.

A quite different perspective provides the story of Ms Latifi, showing that certain elements of the socialist rule genuinely attracted some contemporaries, even those who were not interested at all in politics and who interpret their life retrospectively as completely apolitical. Martin Sabrow and Pavel Kolář's approach in studying socialist dictatorships as 'worlds of meaning' (Sinnwelten) proves very useful when considering such cases (Sabrow, 2007; Kolár, 2007). They argue that certain 'images of rule' (Ordnungsvorstellungen) that did not appear to be political but simply 'natural' were very successful in bringing about legitimation for socialism. In the concrete case, while Ms Latifi stressed several times that she used to lack any interest in politics, she also resolutely showed her support for the socio-political order in socialism. In fact, her experience of socialism as 'normalcy' was shaped by a significant degree of concurrence between her worldview and certain norms propagated by the communist regime:

\footnotetext{
${ }^{7}$ See Obertreis \& Stephan, 2009: 52-3; Jõesalu, 2009. Furthermore, compare this with the following study on the retrospective narrative of a 'normal life' in the German Democratic Republic (GDR) in Fulbrook, 2009.
} 
To me it [punishing state criticism] appeared like a normal thing, because you cannot oppose the paterfamilias. The paterfamilias knows the rules better than you. It is like if my son would say to me: 'You do not know'. Don't I oppose my son?! Because I know more than my son. [...] He [Enver Hoxha] was absolute [enjoyed absolute authority]. He was absolute (tscp. no. 29: 6).

Two concepts stand out: the metaphor of society as a family and the conviction that the paterfamilias is the highest authority. Such views legitimise a number of values the communist regime propagated, such as unity among the people and between people and the state, the avantgarde status of party and ruler, the entitlement of party/ruler to take decisions binding upon the whole society and the obligation of citizens to abide by them automatically. ${ }^{8}$

\section{2 'The suffering could not have been greater'}

Life under the communist regime was terrible, and the 1970s and 1980s were the worst period. This was the tenor of the narrations analysed in this section. The interviewees deplored both the harsh political repression and the extreme poverty, and their life stories suggest that they cultivated a strong inner rejection of socialism already in socialist time. The following analysis reviews the underlying causes behind this stance. Furthermore, as one of the interviewees belonged to a persecuted family, the section reflects on the repressive practices of the communist regime. The fact that some of the interviewees were originally not negatively minded toward socialism, but dissociated themselves from it only after a specific moment or event, offers, moreover, the opportunity to explore key delegitimising factors in the late phase. Finally, the section analyses contemporaries' strategies and practices to adjust to socialism.

In contrast to the interviewees featured in the previous section, those analysed here claimed to have been very interested in politics and to have considered them highly relevant:

Absolutely, yes [I was interested in politics], because politics was at that time connected to our daily life, to our daily bread. [...] Absolutely, yes, no question about it [...] we were all the time, in every moment, up-to-date on what happens, how it happens, how it proceeds (tscp. no. 1: 13).

Mr Naimi, from whom this quote came, was initially relatively positively minded toward socialism. In the late phase, however, he increasingly developed an aversion to it. The following further quotes demonstrate a close interdependency between the interviewee's political stance and his living conditions. Furthermore, they reveal both the legitimising effect of the grand economictechnological progress achieved under the communist regime until the mid-1970s (Bartl, 1995: 261-4) and the delegitimising impact of the dramatic impoverishment of the subsequent phase:

I have experienced the time of torches, too. More terrible could it not be. But when he [Enver Hoxha] brought us the [electric] light, it was a satisfaction, it was something nice. Because of this, we followed his line. He created material well-being (tscp. no. 1: 11).

It [socialism] started nice. When the poverty came, so that we could not eat us fill, than it is obvious: How could we agree with his [Enver Hoxha's] politics?! [...] I did not have [enough] to eat, could not eat me fill (ibid.: 15).

Fortunately, he [Enver Hoxha] left us [did not collectivise] at least the chickens. When there were scrambled eggs to eat, I tell you honestly, I used to think: 'Thank God, mother prepared scrambled eggs'. You cannot, maybe, comprehend this, because you have not experienced such moments ... (ibid.: 17).

An important factor in fuelling an aversion against the regime and a yearning for better living conditions was, in the case of Mr Naimi, the consumption of foreign, mainly Yugoslav media (ibid.: $5,6,10)$. The effect of this practice, which was punishable in socialist Albania, ${ }^{10}$ on the mind-sets and political attitudes of other respondents significantly varied. In Mr Ridvani's account, for example, watching foreign media was described as an occasional entertainment activity, while his

\footnotetext{
${ }^{8}$ For more on the political culture in socialist Albania, see Schmidt-Neke, 1993: 203-14.

${ }^{9}$ Tscp. no. 14: 2.

${ }^{10}$ For more on the illegal watching of foreign broadcasts in socialist Albania, see Idrizi, 2016.
} 
regime aversion was likely largely the result of the primary socialisation, the arrest and torture of his father because of an anonymous denunciation and the purging of one of his cousins from the party in the late 1970s because of the 'bad biography' of his wife (tscp. no. 16). Conversely, for Mr Meti, foreign media seems to have had great political impact; he claims to have frequently listened to the news bulletin of Voice of America and watched a political programme of the 'Yugoslav State Television' that addressed the Albanian audience, interviewing, for instance, persons that had escaped from communist Albania in their native language (tscp. no. 15: 4). Notably, Mr Meti is perhaps the interviewee who most lamented the oppression of human rights and especially freedom of expression, asserting that feeling that one could never in life freely express one's real opinion caused him much suffering (ibid.: 12-13).

In the case of two other interviewees, Mr Zefi and Mr Ndoji, the reasons for strongly rejecting socialism are quite evident. Belonging to a persecuted family, Mr Zefi was constantly subjected to various forms of discrimination. ${ }^{11} \mathrm{Mr}$ Ndoji, in turn, who lived in a remote mountainous area, had seen his cows taken away under the collectivisation campaign, and, consequently, experienced a period of extreme poverty, during which he was afraid for his and his family's very existence. Furthermore, being pious, the regime's ban of religion ${ }^{12}$ and the surveillance of people's private spaces, made him feel extremely restricted in his freedoms - not least because, born in 1932, he had memories of pre-socialism times, too (tscp. no. 14).

How did these contemporaries adapt to conditions they perceived as almost unbearable? Mr Ndoji, who also believed that the 'the big one', Enver Hoxha, saw everything and would draconically punish the smallest deviancy, used to isolate himself from other people. His occupation as a swineherd allowed him to spend time in nature and with animals. In his own words, in the company of pigs he felt more comfortable than with people (ibid.: 8). Meanwhile, Mr Zefi kept hoping that one day the regime would be overthrown by a foreign power and the stigmatised people would be 'liberated'. Furthermore, he endeavoured to maintain a positive atmosphere at home, avoiding complaining or talking about politics (tscp. no. 9: 3, 5-6). For Mr Meti, a strong fear of state repression impelled a form of self-education toward adjusting to the given conditions (tscp. no. 15: 2-6, 11-13). Mr Naimi and Mr Ridvani had similar approaches, but, as young people (born respectively in 1964 and 1960) who had access, through foreign broadcasts, to images of life abroad, the prospect of spending their whole life in poverty and under dictatorship seems to have appeared to them especially depressing (tscp. no. 1: 5-7, 10, 13, 17, 19; tscp. no. 16: 4-5, 9-10).

\section{3 'We did not think [critically], because we had our situation all right' ${ }^{, 13}$ : Arrangement out of opportunism}

Albania's communist regime provided upward social mobility for a considerable section of the country's population. Some of those who benefited enthusiastically supported socialism and genuinely identified themselves with the communist ideals. Meanwhile, many others simply made use of the opportunities as they arose. This section will focus on the second category, while the first will be analysed in the section that follows.

Interviewing people who aligned themselves with the communist regime despite being aware of its 'dark sides' was, unsurprisingly, complicated. Some talked relatively openly, but many were primarily concerned with justifying and even hiding their former motives and actions. The following analysis examines possible motives for why these contemporaries might have chosen to work with the communist regime as well as how they have come to terms with this in post-socialism.

A typical interviewee in this category is Mr Toma. Originating from a poor peasant family, he graduated, under socialism, from agricultural college and got a job, first as a storeman then as a so-

\footnotetext{
${ }^{11}$ Tscp. no. 9. Regarding the discriminatory practices against so-called 'people with a bad biography' in socialist Albania, see Kretsi, 2007b.

${ }^{12}$ In the context of the so-called 'Albanian Cultural Revolution', which was inspired by the 'Great Proletarian Cultural Revolution' in China, Albania's then main ally, the regime outlawed religion, proclaimed Albania to be the first atheistic state of the world and introduced severe punishments for practicing religion. See Bartl, 1993: 608-611.

${ }^{13}$ Tscp. no. $17 / 2$ : 5 .
} 
called 'brigadier', leader of a small work team. Furthermore, he was granted membership to the local party organisation. Mr Toma accepted the chances offered to him gratefully and highly appreciated these professional, social and political advances. Remarkably, the interviewee acknowledged that he had been aware of the regime's political repression, and especially of the discrimination of people with 'bad' political or social background, but argued that he used to exclusively 'mind his own business', since, already at a very young age, he had 'learned' that life is 'unfair' and a 'battle for existence' (ibid.: 7). According to Mr Toma, one of his classmates, who was very talented but had a 'bad biography', was denied admission to higher education, while he, despite having worse grades, was accepted. Emotionally touched at this point of his narration, Mr. Toma claimed that he was then sad about the discrimination of his classmate, but had neither the courage to publicly address it nor the time and energy to continue to innerly lament it, since he had to take care of his own survival. Rejecting the chance to attend college would have been beside the point for Mr Toma, who perceived the fate of stigmatised people as uninfluenceable by actions of 'ordinary' people like him (ibid.: 4, 7).

Similarly, another interviewee, Mr Deda, highlighted these contemporaries' very limited scope of action. Criticising the state and influencing its policies appeared to him as clearly impossible. Accordingly, the interviewee saw nothing wrong with making use of the 'few' chances that were offered. Joining the party to yield an advantage from one's member status, for instance, appeared to him as not morally reprehensible but simply 'cleverness' (tscp. no. 12: 11). Thus, participating at the lowest ranks of the party-state was, it seems, not necessarily driven by ideological conviction, but sometimes by opportunism and pragmatism.

In the case of another interviewee, Mr. Ahmeti, the collaboration with the communist regime was prompted by the interplay of a fear of repression and opportunism. Because of his 'bad biography', he was subjected to severe discrimination and humiliation. Furthermore, an agent of the greatly feared state security service (Sigurimi $i$ Shtetit, referred to as the Sigurimi ${ }^{14}$ ) intimidated him into collaborating as an unofficial informant. Finally, a happening made Mr Ahmeti to give in. His supervisor fired him from his job as a shop assistant and humiliated him in front of his colleagues, claiming that, because of his 'bad biography', he was not reliable and dignified of such work position. Following this, the Sigurimi agent offered Mr. Ahmeti to arrange for a new relatively good job in exchange for collaboration with the Sigurimi. Fearing for his own survival on the one hand, concluding that wider society was hypocritical and selfish on the other hand, Mr Ahmeti decided that he too should pursue his vested interests, without regard to those of others (protocol to tscp. no. 23).

Mr Ahmeti only disclosed his collaboration with the Sigurimi during the 'unofficial' postinterview conversation, after he had assured himself that the recording device was switched off. Evidently, he found talking about his experiences under the communist regime difficult and frightening, but, notably, also important and liberating.

\subsection{II felt a certain pride" ${ }^{, 15}$ : Self-identification with socialism}

Of the 35 contemporary witnesses originally interviewed, around one fifth claimed that they used to strongly support the socialist system. Some indicated that they have since re-evaluated many aspects, but most stressed the 'good sides' of socialism that they seem to miss today. ${ }^{16}$ In fact, while recollecting socialist era, several interviewees referred to the country's difficult post-socialist transition, and the shaping influence of such experiences on the remembrances and interpretation of socialism is sometimes obvious. However, within these narrations, there are also often indications that many interviewees had important reasons to genuinely support socialism already ahead of its fall. This section considers the sources that legitimise(d) socialism both at that time and today.

To the interviewees who most enthusiastically supported socialism belongs Mr. Lahi.

\footnotetext{
${ }^{14}$ For further information on the Sigurimi, see Schmidt-Neke, 1993: 206-208, and Dervishi, 2012.

${ }^{15}$ Tscp. no. 20: 4.

${ }^{16} \mathrm{Cf}$. the following study on nostalgia for socialism in the countries of the former Yugoslavia: Marković, 2007.
} 
Originating from a very poor peasant family, he had managed to graduate from university and become a teacher as well as a member of the local party committee. The interviewee seems to have greatly appreciated this advancement. He attributed his 'success' directly to the party. It appeared self-evident to him that he never could have achieved it, if the communists had not assumed power. According to him, before the communist takeover, poor peasants used to be discriminated against, but the new regime had introduced social justice, vesting marginalised people with human dignity and equal rights (tscp. no. 20:3, 4, 7).

For another interviewee, Mr Qamili, the key integration moment was the land reform enforced by the communist regime shortly after the takeover. ${ }^{17}$ The interviewee established a direct link between this event and his/'people's' loyalty towards the communist ruler: ${ }^{18}$

At that time, we necessarily felt respect for him [Enver Hoxha]. We necessarily felt respect for him, because, after the liberation, he enforced the collectivisation [mistakenly for 'land reform']. [...] So, he granted everybody a bone to suck. [...] Therefore, nobody had the dignity to criticise him [ever after this] (tscp. no. 3/1: 7).

During the interview, Mr Qamili frequently used official communist terminology and reiterated his absolute loyalty to Enver Hoxha, whom he regarded as 'the king of the castle' (ibid.: 8). Similarly, another interviewee, Mr Hasani, almost proudly stated that Enver Hoxha used to punish enemies and all those who did not obey him, and showed appreciation for strength, authority, discipline and homogeneity (tscp. no. 17/1: 2, 5, 12). However, following the recitation of such unambiguous statements, typical of a particular mind-set under socialism and a reproduction of slogans of communist propaganda, at a late stage of his narration, the interviewee told two stories that provide valuable insights into the experiences that have shaped his habitus. First, he had witnessed an acquaintance being intentionally provoked by local communists to express a politically incorrect saying, and be subsequently imprisoned for 13 or 14 years. Second, his brother-in-law had fled the country in the late 1970s, on the same night he had visited Mr Hasani's home. For about one year afterwards, until the escapee returned, the interviewee and his family had lived with the constant fear that the police would come any moment to arrest and intern them, as usually happened with family members of people who had fled. ${ }^{19}$ These two events seem to have eventually traumatised the interviewee. In any case, they brought about the attitude that one should categorically refrain from any act of political incorrectness and not trust anybody, not even relatives and family members. As the interviewee disclosed, he used to be afraid to say anything politically incorrect even to his wife (tscp. no. 17/1: 12). The fact that Mr Hasani's family was not persecuted despite the events described provoked loyalty toward the regime, to which the interviewee felt grateful for having 'shown mercy'. To conclude, Mr Hasani's determined support for the communist regime can be seen to be, to a large extent, the consequence of two traumatic, or at least very frightening, experiences, and of a self-education process toward conformity born out of a fear of persecution. His behaviour shows similarities to, for example, the typical reactions of people who have been traumatised by an interaction with the Soviet political police but have not yet shared their experiences (cf. Golubev, 2009: 268, 272).

\section{Conclusions}

The Albanian socialist system was in its late phase marked by two distinct facets. On the one hand, the communist regime, unlike others in Eastern Europe in the post-Stalin era, continued to employ highly repressive measures, which were directed largely against people with so-called 'bad' political

\footnotetext{
${ }^{17}$ For further information on the land reform, see Bartl, 1995: 243-4.

${ }^{18}$ The way in which land reform and other communist regime measures brought about loyalty among large sectors of the population has already been researched in some other national contexts. See Zimmermann, Haslinger and Nigrin (Eds.), 2010.

${ }^{19}$ While escape was considered treasonous and punishable by at least ten years in prison up to the death sentence, family members of escaped persons were usually sentenced to internment in remote areas. See Minnesota Lawyers International Human Rights Committee, 68-74.
} 
or social background and against real or alleged non-conformists, but traumatised many others, too. On the other hand, the regime enjoyed the loyalty of large sections of the population. Many had benefited from its social policies and therefore felt obliged. Some others aligned themselves to the regime out of opportunism. Those who were socialised in socialism typically took the given conditions for granted, never questioning their legitimacy. Meanwhile, many others adapted themselves over time to a system they perceived as eternal and to a regime that seemingly draconically punished the smallest act of non-conformism. While self-education toward conformism was widespread, more than a few contemporaries internalised the fundamental 'rules' of the socialist order, first of all subordination to the state and reverence of the ruler, whom many, due to their patriarchal worldview, regarded as the 'king of the castle'.

In the context of the dramatic impoverishment and the radical state measures of the late phase, some contemporaries increasingly disassociated themselves from the communist regime. However, an attitude of minding only one's own business - meaning focusing almost exclusively on mastering one's own survival, while regarding the wider spheres of politics as the state's exclusive domain - prevailed. Not only was public state criticism absent, but also complaining about general shortages in private circles was largely taboo.

Interviewing contemporaries of Albania's (late) socialist era, it becomes clear that most of these individuals have to recollect many experiences, including traumatic and shameful ones, which they have not come to terms with yet. The interviews are full of reflective moments that appear to have otherwise not been evoked during the difficult post-socialist transition. Many narratives take unexpected turns. Enthusiastic supporters of socialism transpire to have been traumatised by its repressive character. Others who claim to have been completely indifferent toward politics and ideology go on to show strong support for the norms of the socialist 'Sinnwelt'.

Concluding, this study's findings suggest that, in Albania, because the process of coming to terms with the socialist past has, both at the collective and individual level, barely begun, no clear and consolidated remembrance patterns have yet emerged. Instead, how contemporaries remember socialism today (if they do so at all), is characterised by great heterogeneity, uncertainties and many contradictions, of which both individuals and society still have to make sense.

\section{Acknowledgement}

The article was funded within the Post-DocTrack Pilot Program of the Austrian Academy of Sciences.

\section{References}

\section{Primary Sources: Interviews}

Transcript no. 1, interview with Mr Naimi (born in 1964) on 2 Jan. 2012.

Transcript no. 3/1, interview with Mr Qamili (born in 1938) on 11 Mar. 2012.

Transcript no. 5, interview with Mr Guri (born in 1939) on 20 Mar. 2012.

Transcript no. 9, interview with Mr Zefi (born in 1950) on 3 Apr. 2012.

Transcript no. 12, interview with Mr Deda (born in 1956) on 10 Apr. 2012.

Transcript no. 14, interview with Mr Ndoji (born in 1932) on 15 Apr. 2012.

Transcript no. 15, interview with Mr Meti (born in 1949) on 16 Apr. 2012.

Transcript no. 16, interview with Mr Ridvani (born in 1960) on 2 Aug. 2012.

Transcript no. 17/1, interview with Mr Hasani (born in 1941) on 10 Aug. 2012.

Transcript no. 17/2, interview with Mr Toma (born in 1954) on 10 Aug. 2012.

Transcript no. 20, interview with Mr Lahi (born in 1945) on 21 Aug. 2012.

Transcript no. 23, interview with Mr Ahmeti (born in 1958) on 3 Sept. 2012.

Transcript no. 25, interview with Ms Brahja (born in 1962) on 6 Sept. 2012.

Transcript no. 29, interview with Ms Latifi (born in 1944) on 20 Sept. 2012. 


\section{Secondary Literature}

Amnesty International (1984). Albania: Political Imprisonment and the Law. London.

Amy, L. E. (2010). Re-Membering in Transition: The Trans-National Stakes of Violence and Denial in PostCommunist Albania. History of Communism in Europe, 1, 207-24.

Bartl, P. (1993). Religionsgemeinschaften und Kirchen. In K.-D. Grothusen (Ed.), SüdosteuropaHandbuch/Handbook on South Eastern Europe, vol. VII: Albanien (pp. 587-614). Göttingen: Vandenhoeck \& Ruprecht.

Bartl, P. (1995). Albanien: Vom Mittelalter bis zur Gegenwart. Regensburg: Pustet.

Dervishi, K. (2012). Sigurimi i Shtetit, 1944-1991: Historia e policisë politike të regjimit komunist. Tirana: 55.

Fulbrook, M. (1995). Anatomy of a Dictatorship: Inside the GDR, 1949-1989. Oxford: Oxford University Press.

Fulbrook, M. (2009). 'Normalisation' in the GDR in Retrospect: East German Perspectives on Their Own Lives. In M. Fulbrook (Ed.), Power and Society in the GDR, 1961-1979. The 'Normalisation of Rule'? (pp. 278319). New York, NY, and Oxford: Berghahn Books.

Golubev, A. (2009). Remembering and Re-Evaluating "Ashamed" Experience: Interaction with the Political Police in 1945-1956 in the Memory of the Soviet Karelian Population. In J. Obertreis \& A. Stephan (Eds.), Erinnerungen nach der Wende: Oral History und (post)sozialistische Gesellschaften/ Remembering after the Fall of Communism: Oral History and (Post-)Socialist Societies (pp. 263-74). Essen: Klartext.

Grothusen, K.-D. (Ed.) (1993). Südosteuropa-Handbuch/Handbook on South Eastern Europe, vol. VII: Albanien. Göttingen: Vandenhoeck \& Ruprecht.

lacono, F., \& Këlliçi, K. L. (2015). Of Pyramids and Dictators: Memory, Work and the Significance of Communist Heritage in Post-Socialist Albania. Arqueologia Publica, 5, 97-122.

lacono, F., \& Këlliçi, K. L. (2016). Exploring the Public Perception of Communist Heritage in Post-Communist Albania. EX Novo, 1/1, 55-69.

Idrizi, I. (2014). Zwischen politischer Instrumentalisierung und Verdrängung: Die Auseinandersetzung mit dem Kommunismus in Öffentlichkeit, Geschichtspublizistik und Historiographie im postkommunistischen Albanien. Jahrbuch für Historische Kommunismusforschung, 93-106.

Idrizi, I. (2016). "Magic Apparatus" and "Window to the Foreign World"? The Impact of Television and Foreign Broadcasts on Society and State-Society Relations in Socialist Albania. In K. Bönker, J. Obertreis and S. Grampp (Eds.), Television Beyond and Across the Iron Curtain (pp. 227-56). Newcastle upon Tyne: Cambridge Scholars Publishing.

Jõesalu, K. (2009). Erfahrungen und Darstellungen - das sowjetische Alltagsleben in der estnischen Erinnerungskultur. In Obertreis \& Stephan (Eds.) (pp. 329-43).

Kati, F. (2004). Antologjia e plagëve: Nën terrorin komunist. Tirana: Natyra 2001.

Instituti i Studimeve për Krimet dhe Pasojat e Komunizmit (Ed.) (2014/2015/2016). Zërat e kujtesës, Vol. 1-3. Tirana: Westprint/ Maluka/ Kristalina. KH.

Kluge, S. (2000). Empirisch begründete Typenbildung in der qualitativen Sozialforschung. Forum Qualitative Sozialforschung/Forum: Qualitative Social Research, 1(1), Art. 14. [Online] Available: http://www.qualitative-research.net/index.php/fqs/article/view/1124/2497\#gcit (July 14, 2017).

Kolář,P. (2007). Sozialistische Diktatur als Sinnwelt: Repräsentationen gesellschaftlicher Ordnung und Herrschaftswandel in Ostmitteleuropa in der zweiten Hälfte des 20. Jahrhunderts (Projektbericht). Potsdamer Bulletin für Zeithistorische Studien, 40/41, 24-9. [Online] Available: https://zzfpotsdam.de/sites/default/files/publikation/Bulletin/kolar_sozialistischediktatur.pdf (July 14, 2017).

Kretsi, G. (2007). Verfolgung und Gedächtnis in Albanien: Eine Analyse postsozialistischer Erinnerungsstrategien. Wiesbaden: Harrassowitz.

Kretsi, G. (2007). "Good and Bad Biography": The Concept of Family Liability in the Practice of State Domination in Socialist Albania. In U. Brunnbauer, A. Helmedach, \& S. Troebst (Eds.). Schnittstellen: Gesellschaft, Nation, Konflikt und Erinnerung in Südosteuropa. Festschrift für Holm Sundhaussen zum 65. Geburtstag (pp. 175-88). Munich: Oldenbourg.

Lelaj, O. (2016). Let's Talk about "Communism"! Notes on Politics, Knowledge Production and Ethics in Contemporary Albania. Rivista di Scienze Sociali. [Online] Available: http://www.rivistadiscienzesociali.it/lets-talk-about-communism-notes-on-politics-knowledge-productionand-ethics-in-contemporary-albanian-i/ (July 14, 2017).

Marković, P. J. (2007). Der Sozialismus und seine sieben "S"-Werte der Nostalgie. In U. Brunnbauer \& S. Troebst (Eds.). Zwischen Amnesie und Nostalgie: Die Erinnerung an den Kommunismus in Südosteuropa (pp. 153-64). Cologne, Vienna and Weimar: Böhlau.

Minnesota Lawyers International Human Rights Committee (1990). Human Rights in the People's Socialist Republic of Albania. Minneapolis, MN.

Niegelhell, A., \& Ponisch, G. (2001). Wir sind immer im Feuer: Berichte ehemaliger politischer Gefangener im kommunistischen Albanien. Vienna, Cologne, and Weimar: Böhlau. 
Obertreis J. \& Stephan, A. (2009). Memory, Identity and "Facts": The Methodology of Oral History and Researching (Post-)Socialist Societies (Introduction). In Obertreis \& Stephan (Eds.) (pp. 37-61).

Pipa, A. (1990). Albanian Stalinism: Ideo-Political Aspects. Boulder, CO/New York, NY: Columbia University Press.

Prifti, P. R. (1978). Socialist Albania since 1944: Domestic and Foreign Developments. Cambridge, MA/London: MIT.

Sabrow, M. (2007). Sozialismus als Sinnwelt: Diktatorische Herrschaft in kulturhistorischer Perspektive. Potsdamer Bulletin für Zeithistorische Studien, 40-41, 9-23. [Online] Available: https://zzfpotsdam.de/sites/default/files/publikation/Bulletin/sabrow_sinnwelt.pdf (July 14, 2017).

Schmidt-Neke, M. (1993). Politisches System. In Grothusen (Ēd.), (pp. 169-242).

Schmidt-Neke, M. (2009). Zwischen Kaltem Krieg und Teleologie: Das kommunistische Albanien als Objekt der Zeitgeschichtsforschung. In O. J. Schmitt \& E. A. Frantz (Eds.) Albanische Geschichte: Stand und Perspektiven der Forschung (pp. 131-47). Munich: Oldenbourg.

Tönnes, B. (1980). Sonderfall Albanien: Enver Hoxhas "eigener Weg" und die historischen Ursprünge seiner Ideologie. Munich: Oldenbourg.

Vullnetari, J., \& King, R. (2014). 'Women Here are Like at the Time of Enver [Hoxha]...': Socialist and PostSocialist Gendered Mobility in Albania. In K. Burrell, \& K. Hörschelman (Eds.), Mobility in Socialist and Post-Socialist States: Societies on the Move (pp. 122-47). Basingstoke: Palgrave Macmillan.

Vullnetari J., \& King, R. (2016). 'Washing Men's Feet': Gender, Care and Migration in Albania during and after Communism. Gender, Place and Culture, 23/2, 198-215.

Vullnetari, J., \& King R. (2016). From Shortage Economy to Second Economy: An Historical Ethnography of Rural Life in Communist Albania. Journal of Rural Studies, 44, 198-207.

Woodcock, S. (2007). The Absence of Albanian Jokes about Socialism, Or Why Some Dictatorships Are Not Funny. In C. Hamilton, M. Kelly, E. Minor, \& W. Noonan (Eds.), The Politics and Aesthetics of Refusal (pp. 51-66). Newcastle: Cambridge Scholars Publishing.

Woodcock, S. (2014). 'Against a Wall': Albania's Women Political Prisoners' Struggle to be Heard. Cultural Studies Review, 20/2, 39-65.

Woodcock, S. (2016). Life Is War: Surviving Dictatorship in Communist Albania. Bristol: HammerOn Press.

Zimmermann, V., Haslinger, P., \& Nigrin, T. (Eds.) (2010). Loyalitäten im Staatssozialismus: DDR, Tschechoslowakei, Polen. Marburg: Herder Institut. 